\title{
Pink and white shrimps from the Brazilian coast: pigment identification, antioxidant activity and microbial quality under different freezing-times
}

\author{
Ana Maria Queijeiro LÓPEZ1* (D), Flávia Adaís Rocha dos SANTOS ${ }^{1}$, Everton Santos MARTINS ${ }^{1}$, \\ Amanda Lys dos Santos SILVA ${ }^{1}$, Elane Cristina Lourenço dos SANTOS ${ }^{1}$.
}

\begin{abstract}
Shrimps fishing, especially the pink (Farfantepenaeus brasiliensis and F. subtilis) and the white (Litopenaeus schmitti) ones, are relevant for the Brazilian Northeast economy, and their price depends on their aspect-quality. They are rich in lipids/proteins, which are a target for autolytic and microbial enzymes. These may not change the shrimps' appearance but generate substances that may cause poisoning, as histamines. This work compared the microbial quality of fillets and shells of these three shrimps, harvested in two years, after cooking and storage under different freezing times (0-90 days), as well as the total carotenoids (TC) and antioxidant activity (AA\%) of ethanolic extracts from all the samples, using spectrophotometry and DPPH test. None histaminogenic and few mesophilic bacteria were isolated (all Gram+ species of Corynebacterium, Listeria, Arthrobacter, Bacillus and Erysipelothrix), but in lower number than the tolerability limit. The TC and AA\% of fresh shells from time "zero" were always higher than those of fillets, mainly for F. subtilis. Cooking increased TC and AA\% of fillets, but reduced them in shells, and both parameters declined along the freezing. Thin-layer chromatography and spectrophotometric scanning of all the extracts and standards evidenced astaxanthin as the main carotenoid.
\end{abstract}

Keywords: antioxidant; astaxanthin; biogenic amines; carotenoids; functional food; microbiota.

Practical Application: Knowledge of the health condition from different parts of distinct shrimps harvested in two seasons of the Northeast coast of Brazil, and their concentration of total carotenoids, as well the identification of these pigments and their antioxidant activity, aiming at a possible use of shrimps' residues as a source of nutraceuticals.

\section{Introduction}

Shrimps are nutrient-rich food due to their high content in proteins, lipids, minerals (calcium carbonate and phosphates), chitin, and carotenoids (An et al., 2018; Yuan et al., 2011). They have economic and social importance, once that, over the last 50 years, their production, processing and commercialization have expanded greatly in several countries (Food and Agriculture Organization, 2015), and in the case of Brazil, its broad coastline has ecological and biological parameters exceptionally favorable, all over the year, to shrimps growth. Their market value, however, is predominantly affected by the appearance or their shells, which play a significant role to the consumer-acceptance, and it is affected by the carotenoids content.

Carotenoids are tetraterpenoids (C40) containing 2-15 conjugated double bonds (Figure 1), with cis and trans configurations (Harrison \& Quadro, 2018; Rao et al., 2012), being the most important class of natural pigments responsible for the orange, yellow and red colors of a plenty of superior plants, algae, microorganisms and animals (Arvayo-Enríquez et al., 2013).

With the exception of a few aphids species (Moran \& Jarvik, 2010), animals are unable to synthesize such compounds, which they obtain in their diet, mainly food plants, using them for pigmentation, protection from light/oxidative stress (as in the skin and macular pigment of the human fovea) and, in the case of the ones containing non-substituted $\beta$-ionone rings, as precursors of vitamin A upon conversion into retinoids (Harrison \& Quadro, 2018). Therefore, carotenoids have an important role in the prevention of human diseases, improving the immune system, inhibiting the development of certain types of neoplasms, fighting against the harmful effects of free radicals to cellular components (such as proteins, lipids, lipoproteins and deoxyribonucleic acid), which represents one of the factors responsible for the onset of cancer, degenerative diseases and aging (Arvayo-Enríquez et al., 2013; Bose \& Agrawal, 2007; Eliassen et al., 2015; McCall et al., 2018; Wu et al., 2015; Yuan et al., 2011).

The structure of carotenoids may undergo hydrogenation, dehydrogenation, double bond migration, shortening or chain extension, rearrangement, isomerization, oxidation, cyclization, introduction of substituents or combination of these processes, resulting in more than 700 different natural molecules classified in four groups - hydrocarbons (carotenes), ketonic or hydroxylic derivatives (xanthophylls), carotenoid acids, xanthophylls esters and a wide structural diversity and countless chemical and biological properties (Mezzomo \& Ferreira, 2016). Their separation/ identification was possible with the evolution of chromatographic and spectroscopic methods, but their effective biological activities 

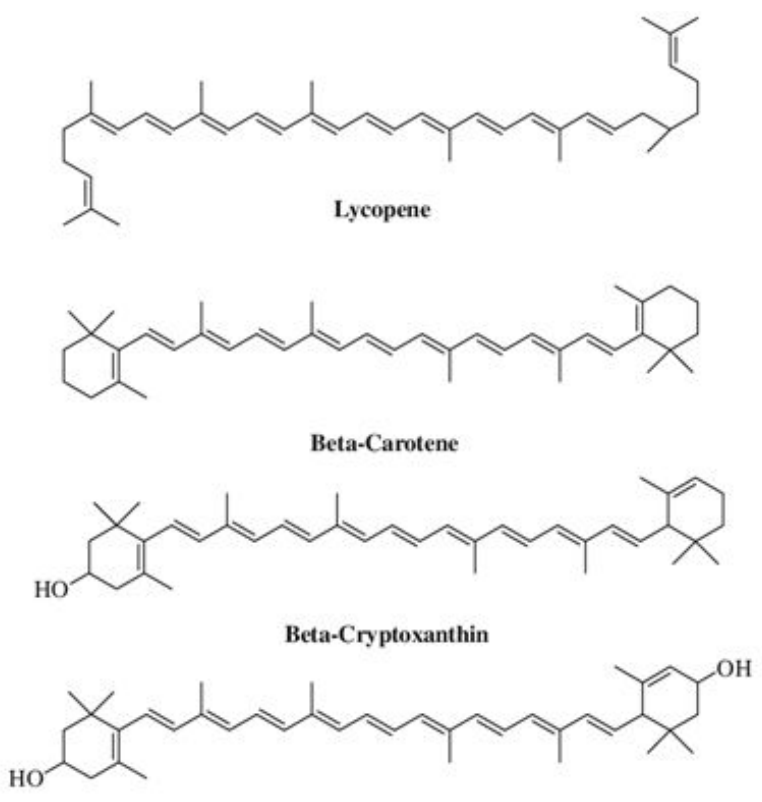

Lutein
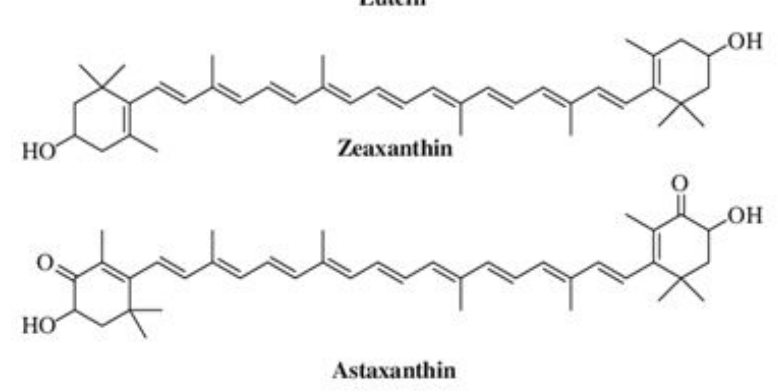

Figure 1. Chemical structure of some nonpolar (carotenes) and polar (xanthophylls) carotenoids (Arvayo-Enríquez et al., 2013).

has been distinguished in only ca. of 7\% of them (An et al., 2018; Harrison \& Quadro, 2018; Mezzomo \& Ferreira, 2016), what justify the increasing interest in such molecules. Astaxanthin (3,3'-dihydroxy- $\beta, \beta$-carotene- $4,4^{\prime}$-dione) - Figure 1 - and its esters, are the main xanthophyll in some fishes (salmon and trout), as well as in most shrimps, prawns, lobsters and crabs, giving to their tissues the red-orange color, especially after cooking (Okada et al., 1994; An et al., 2018; He et al., 2017).

Therefore, concerning the commercial relevance of the pink shrimps Farfantepenaeus brasiliensis (Latreille, 1817) and F. subtilis (Perez-Farfante, 1967), as well as of the white shrimp Litopenaeus schmitti (Burkenroad, 1936) harvested in the coast of Maceió (State of Alagoas, Brazil), the purpose of this study was to evaluate the effects of seasonality, cooking, and time under freezing on the carotenoid content, antioxidant activity and microbial quality of these sea-food.

\section{Materials and methods}

\subsection{Chemical reagents and preparation of shrimp samples}

Chemical standards (Sigma-Aldrich) of astaxanthin (1044210 USP, of Haematococcus pluvialis) and $\beta$-carotene (22040-1G-F) were stored under refrigeration $\left(4-6^{\circ} \mathrm{C}\right)$. All the organic solvents were analytical grade, and the water was always distilled deionized (DDW).

Batches of $4 \mathrm{~kg}$ of each species of shrimp - Farfantepenaeus brasiliensis and F. subtilis, as well as Litopenaeus schmitti, were acquired immediately after fishing in the coast of Maceió-Al/Brazil, respecting the Brazilian legislation against immature fishing, at September/2015 and January/2016, in a fishery-municipal market of Ponta Verde-beach. Each batch was then packed in plastic bags, deposited into Styrofoam boxes containing ice, and transported to the "Laboratory of Biochemistry of Parasitism and Environmental Microbiology" of the Institute of Chemistry and Biotechnology from the Federal University of Alagoas (LBPMA/IQB/UFAL), to perform the assays and replications $(n=3)$. There, the batches of each species were previously washed with sterile DDW and their head and intestines were removed. For the experiments, only the fillets and shells (from the exoskeleton, cephalothorax, tail and legs) of each species were used, but they were divided in two groups - the first $(2 \mathrm{~kg}$ ) for in natura (raw) studies and the second group $(2 \mathrm{~kg}$ ) for cooking in $1 \mathrm{~L}$ of DDW during $12 \mathrm{~min}$ at $99 \pm 1{ }^{\circ} \mathrm{C}$. Aliquots of fillets $(30 \mathrm{~g})$ and of shells $(15 \mathrm{~g})$ of each species and group (in natura and cooked) were measured and separated for chemical and microbiological analyzes at time "zero". Similar aliquots were packed in sterile plastic bags and storage under freezing $\left(-10^{\circ} \mathrm{C}\right)$ for 45 and 90 days, for submission to the same analyzes.

\subsection{Chemical analysis}

\section{Shrimps extracts}

The aliquots of raw fillet, cooked fillet, raw shells, and cooked shells at zero time and at different storage times under freezing (45 and 90 days) were subjected to the extraction of carotenoids by homogenization in a blender for $5 \mathrm{~min}$, using $100 \mathrm{~mL}$ of the mixture ethanol p.a.: acetone p.a. (1:1 v:v) for each $30 \mathrm{~g}$ of sample. Then, the homogenates were centrifuged $\left(3,801 \times g\right.$, at $4{ }^{\circ} \mathrm{C}$, for $20 \mathrm{~min}$, in a Sigma centrifuge $\left.2 \mathrm{~K} 15\right)$ and the supernatants were placed in an amber flask, while the mass of pellets was measured and again washed with the same solvent system (mass-proportional volume) for $5 \mathrm{~min}$. The pellet that still had pigment was subjected to another extraction, to remove all pigments from the precipitate. The second and third supernatants were added to the first, and each homogenized extract was collected in a separating funnel containing $75 \mathrm{~mL}$ of hexane, $300 \mathrm{~mL}$ water, and $1.5 \mathrm{~g} \mathrm{NaCl}$, to separate and remove the water-soluble compounds. Funnels were kept in dark for $20 \mathrm{~min}$ and shaken once. Hexane extracts were vacuum filtered through Whatman qualitative cellulose filter $(\cong 42.5 \mathrm{~mm}$ in diameter), dehydrated by anhydrous sodium sulfate, poured in a roto-evaporator flask, submitted to evaporation at $40{ }^{\circ} \mathrm{C}$ and re-constituted with ethanol and poured in new amber flasks before stored in a freezer at $-10^{\circ} \mathrm{C}$ until the following day, when chemical determinations were.

\section{Quantification of total carotenoids content}

The total carotenoid (TC) content was determined by spectrophotometry as described by Schiedt \& Liaaen-Jensen 
(1995). Thus, the absorbance at $472 \mathrm{~nm}$ of $1 \mathrm{~mL}$ of each ethanolic extract was measured using a FEMTO 800XI spectrophotometer. The reference blank corresponded to $1 \mathrm{~mL}$ of ethanol p.a. The content of carotenoid present in $1 \mathrm{~mL}$ of extract was calculated (Equation 1):

$T C=A \times Y \times 1000 / 2100 \times 100$

in which "TC" corresponds to the mass of total carotenoids in $\mathrm{mg}$, "A" to the absorbance of $\lambda_{\max }$ " $\mathrm{Y}$ " to the volume of sample in $\mathrm{mL}$, and $2100=1 \%$ of the extinction coefficient from the mass of the extract in a cuvette (width $1 \mathrm{~cm}$ ) of the specific absorbance of astaxanthin, the main carotenoid in shrimps, in ethanol. The determinations were performed in triplicates $(n=3)$.

\section{Determination of Antioxidant Activity (AA\%)}

The measurement of the DPPH radical scavenging activity was performed as described by Je et al. (2009). For this, $2.0 \mathrm{~mL}$ of $0.15 \mathrm{mM}$ ethanolic solution of DPPH were transferred to test tubes containing each final ethanolic extract of carotenoids $(2.0 \mathrm{~mL})$, obtained as described in item 2.3, and leaved to rest for $30 \mathrm{~min}$ in the dark. Then, the absorbance values of $1.0 \mathrm{~mL}$ of the reaction mixture were read at $517 \mathrm{~nm}$ using a UV-spectrophotometer (FEMTO 800XI). The scavenging activity percentage (AA\%) was calculated (Equation 2):

$$
A A \%=100-\left[(\text { sample }- \text { reference }) \times \frac{100}{\text { control }}\right]
$$

Screening of solvents for astaxanthin and $\beta$-carotene extraction and identification

A mixture (of three types of astaxanthin standards (free astaxanthin + mono and diester of astaxanthin) $(4 \mathrm{mg})$ and $\beta$-carotene $(50 \mathrm{mg})$ was added to four Falcon-tubes. Then, $2 \mathrm{~mL}$ of one of the tested solvents (water, ethanol, propanone and hexane) was added in each tube, aiming to analyze the solubility/extraction efficiency. To maximize the extraction, the tubes were transferred to a water-bath for $15 \mathrm{~min}$ at $40^{\circ} \mathrm{C}$, and then centrifuged $(3801 \times g$, $10 \mathrm{~min}, 5^{\circ} \mathrm{C}$ ). After that, the solutions were transferred to amber flasks and frozen at $-10^{\circ} \mathrm{C}$ until further analysis. The standards were partially characterized by thin layer chromatography (TLC), according to the methodology described by Lorenz (1998). For this, silica gel $60 \mathrm{~F}_{254 \mathrm{~nm}}$ plate (aluminum) was previously activated (heating at $50{ }^{\circ} \mathrm{C}, 15 \mathrm{~min}$ ). As the shrimps' ethanolic extracts (species, fillet and shell, raw and cooked) contained less than 5\% carotenoids, an aliquot of $4.0 \mathrm{~mL}$ of each one was subjected to solvent-evaporation to $0.5 \mathrm{~mL}$ in a Shel Lab shaker, model SSI3-2 (constant stirring at $100 \mathrm{rpm}, 40^{\circ} \mathrm{C}$ ). Then, an aliquot $(150 \mu \mathrm{L})$ of each concentrated extract was applied at the origin of the plate, with the aid of a capillary tube, and submitted for $30 \mathrm{~min}$ to a propanone: hexane mixture solvent system 1:3(v: v), as mobile phase. After that, the plate was removed from the chromatographic vessel and the Rfs of the bands were immediately estimated.

\section{Statistical analyses}

TC and AA\% data were submitted to analysis of variance. The means of triplicates were compared by the Tukey test $(5 \%$ probability), using the statistical programs Genes (Cruz, 2013) and SAS (Statistical Analysis System), version 9.4m6 (SAS Institute Inc., 2018).

\subsection{Detection of total and histamine-producing bacteria}

The separated aliquots (30 or $15 \mathrm{~g}$ ) of groups 1 (in natura shrimp) and 2 (cooked shrimp), obtained as above mentioned, were submitted to microbiological analysis at time "zero" and after 45 and 90 days of freezing storage. In total, 12 samples were analyzed according to the following code: first, three shrimp species [white, L. schmitti (LS), or pink, F. brasiliensis (FB) and F.subtilis (FS)]; then, parts of the crustaceans, fillets (F) or shells (C), and mode of preparation and storage, in natura (IN) or after the heat treatment (ATT) and storage time under freezing (0-90 days). The aliquots of each sample (fillets and shells) were placed in $0.1 \%$ peptone water (respectively 250 or $125 \mathrm{~mL}$ ) and homogenized using a piston homogenizer. From the suspensions, successive deciduous dilutions were prepared and $1 \mathrm{~mL}$ of the $10^{-2}$ dilution was inoculated on agar Niven medium (tryptone $0.5 \%$, yeast extract $0.5 \%$, L-histidine $2.7 \%, \mathrm{HCl} 0.5 \%, \mathrm{NaCl} 0.5 \%, \mathrm{CaCO}_{3} 0.1 \%$, agar $2.0 \%$, and cresol red $0.02 \%$, with overlay of the same medium for the count of mesophilic and psychotropic aerobic microorganisms and presumptive histamine-positive bacteria), into Petri dish, using the pour plate technique (Silveira et al., 2001). The plates were incubated $\left(35^{\circ} \mathrm{C}\right.$ and $15^{\circ} \mathrm{C}$, respectively for 48 and $72 \mathrm{~h}$ ) (Brasil, 2003), and then, the total count of colony forming units (CFU) per plate of mesophilic $\left(35^{\circ} \mathrm{C}\right)$ and psychotropic $\left(15^{\circ} \mathrm{C}\right)$ bacteria, and the typical presumptive histamine-positive ones (characterized by the presence of a purplish halo, indicating the alkalization of the medium by the presence of amine) was provided and the CFU g-1 of sample was estimated (Silveira et al., 2001; Mavromatis \& Quantick, 2002).

For confirmation of histamine-positive bacteria, colonies with purplish halo were inoculated into tubes containing modified Niven broth $(0.5 \%$ tryptone, $0.5 \%$ yeast extract, L-histidine $2 \%$, $0.5 \% \mathrm{NaCl}, 0.02 \%$ Bromo cresol red) and inverted Durham's tube. Positive results showed gas presence and purple coloration in the Durham's tubes. The colonies of histamine-positive or not bacteria were re-isolated in modified Niven agar and identified using classical morpho-biochemical tests (Cullimore, 2019) plus the API-20E ${ }^{\circledast}$ Enteric Identification System kit (BioMérieux, Marcy l'Etoile, France), where each isolate was inoculated and incubated according to the manufacturer's instructions, and analyzed as Nucera et al. (2006).

The bacteria were also assessed for their spoilage potential, being checked for their proteolytic, lipolytic and amylolytic properties, as well as their ability for reduction of trimethylamine oxide to trimethylamine, according to Chandrasekaran et al. (1985).

\section{Results and discussion}

\subsection{Total carotenoids of different parts of shrimps (before or after cooking and freezing)}

Regarding the aspect of the samples, the first observation (Figure 2) was that heat-treatment affected in different ways the content of pigments in fillets and shells of the three studied shrimps. 
In natura fillets at time "zero" were lighter and more pinkish or grayish-white than the cooked ones, which became orange (especially on the external part), being this difference more pronounced in F. subtilis. In fish, carotenoid-based body coloration is influenced by diet and physiology, being positively related to mating success and social dominance (Maan \& Sefc, 2013). Then, the type, concentration and bioavailability of carotenoids influence the cooked fishes/crustaceans color.

The color variation after heating is due to alterations in the interactions between carotenoids and other biomolecules. In order to enhance their solubility in aqueous cellular environments, for instance, the highly hydrophobic carotenoids form complexes with proteins on membranes. This results in a large (higher than $100 \mathrm{~nm}$ ) red bathochromic shift in their absorption spectrum (Schiedt \& Liaaen-Jensen, 1995), due to a combination of effects induced by binder-protein, such as strong non-covalent interactions disrupting the electrical structure of carotenoids (Tapiero et al., 2004). Such interactions are easily broken when subjected to temperatures above $60{ }^{\circ} \mathrm{C}$, releasing the pigment and altering shrimp color (Dias \& Ferreira, 2015).

In addition to this change and also to some proteins denaturation after heat treatment, the growth in the contents of carotenoids in the cooked shrimps fillets may also be explained by the fact that such edible parts have much more water than the shells, and this moisture is reduced during cooking, concentrating the other biomolecules. Pedrosa \& Cozzolino (2001), for instance, showed that in natura fillets of the prawn Penaeus brasiliensis, harvested in the Northeastern coast of Brazil (Natal, Rio Grande do Norte), lost around 39\% of its original moisture (88.4\%) after cooking, and this concentrated its in natura protein (10.6\%) and lipids $(0.36 \%)$ contents in about $57 \%$ and $333 \%$. The shells, however, stores less water than the fillets and this content is better protected by the insoluble polysaccharide structure of chitin (25-30\% of the shells composition), so that even after drying shrimp shells at $105{ }^{\circ} \mathrm{C}$ for $24 \mathrm{~h}$, only about $9.25 \%$ of water is lost (Cavalcanti et al., 2016). Then, the cooking of shells for a short time produce even lower reduction in their water content, avoiding the significant concentration of their proteins, minerals and lipids such as carotenoids in comparison to the in natura shells.

As shown in Table 1, for the ethanolic extracts of fillets and shells (raw or cooked), of the three shrimps harvested in September/2015 and January/2016, the TC were significantly reduced along the time of storing under freezing for 90 days, being higher always in samples from the time "zero" and specially in shells $(\rho<0.05)$. The highest contents for the in natura fillets and shells at the initial time were found in F. subtilis (respectively 3.49 and $9.16 \mu \mathrm{g} \mathrm{g}^{-1}$ for the harvest of September/2015, and 2.82 and $10.63 \mu \mathrm{g} \mathrm{g}^{-1}$ for the harvest of January/2016).

The TC in extracts of fillets (Table 1) of the three shrimps were higher in heat-treated samples than in non-cooked ones $(\rho<0.05)$, independent of the time interval under freezing and harvest season, being generally higher in F. subtilis. For the cooked F. subtilis fillets, the increases over the freezing storage interval were about 48 to 55\% for samples of September 2015 and from 35 to $67 \%$ for samples of January 2016, in relation to the uncooked ones. Regarding the TC of cooked F. brasiliensis fillets, their contents in relation to the uncooked ones increased around 35 to $70 \%$ for samples of September 2015 and 17 to $35 \%$ for samples of January 2016. For cooked L. schmitti fillets compared to uncooked ones, the increases in TC were about 73 to $98 \%$ in samples of September 2015 and ca. 300\% in samples of January 2016.

Regarding the ethanolic extracts of the cooked shells of the three studied shrimps, independent of the interval under freezing and season of harvesting, their contents of carotenoids reduced in comparison to the non-cooked ones, being still higher in F. subtilis in relation to the other species (Table 1). Such reductions detected in cooked shells of $F$. subtilis were ca. $15 \%$ over the storage time in 2015 and $7-13 \%$ in 2016, while for cooked shells of $F$. brasiliensis, in relation to the in natura ones, the TC decreased about $9-12 \%$ in 2015 and $10-19 \%$ in

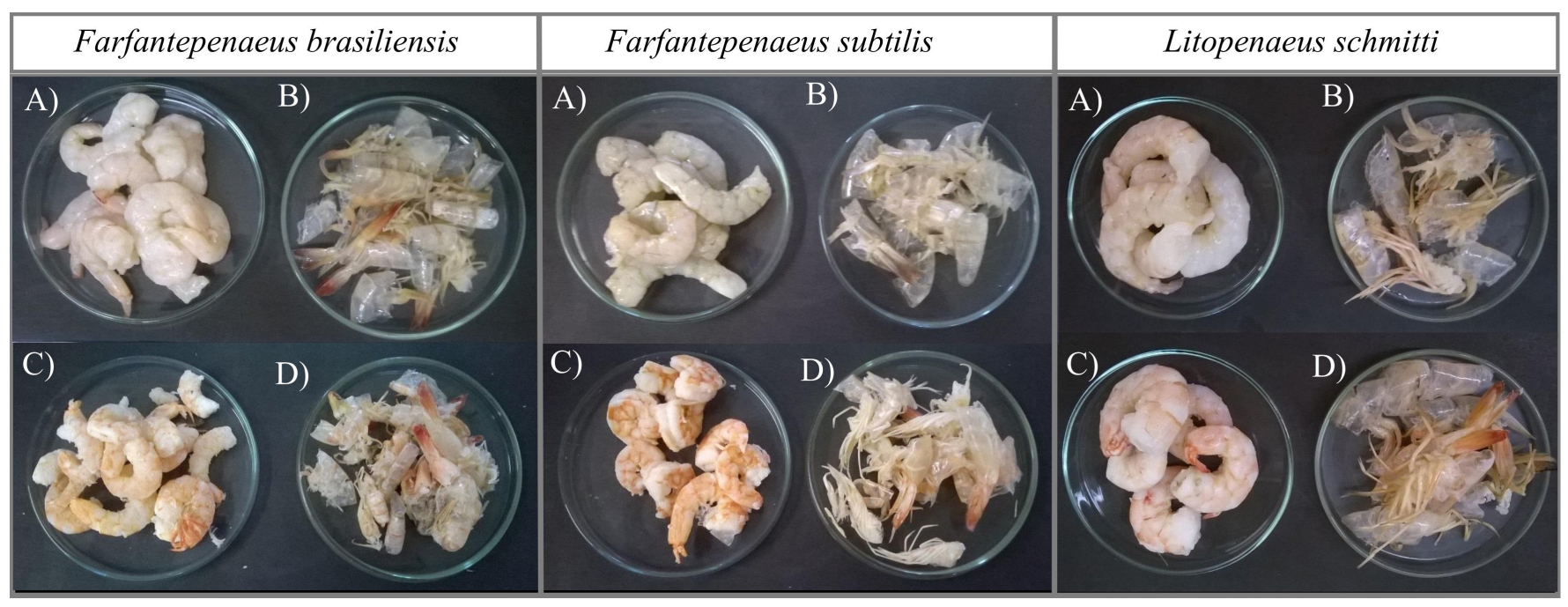

Figure 2. Aliquots of the in natura or cooked fillets (30g, A and C) and shells (15 g, B and D) of the pink (Farfantepenaeus brasiliensis and F. subtilis) and white shrimp (Litopenaeus schmitti), harvested on the coast of Maceió-Alagoas/Brazil. 
Table 1. Total content of carotenoids ( $\mu$ g. $\left.\mathrm{g}^{-1}\right)$ in ethanolic extracts from fillet and shells of pink (Farfantepenaeus brasiliensis and F. subtilis) and white (Litopenaeus schmitti) shrimps (in natura or cooked) samples, analyzed immediately after acquisition and treatment (time "zero") or after storing under different freezing intervals (45 and 90 days).

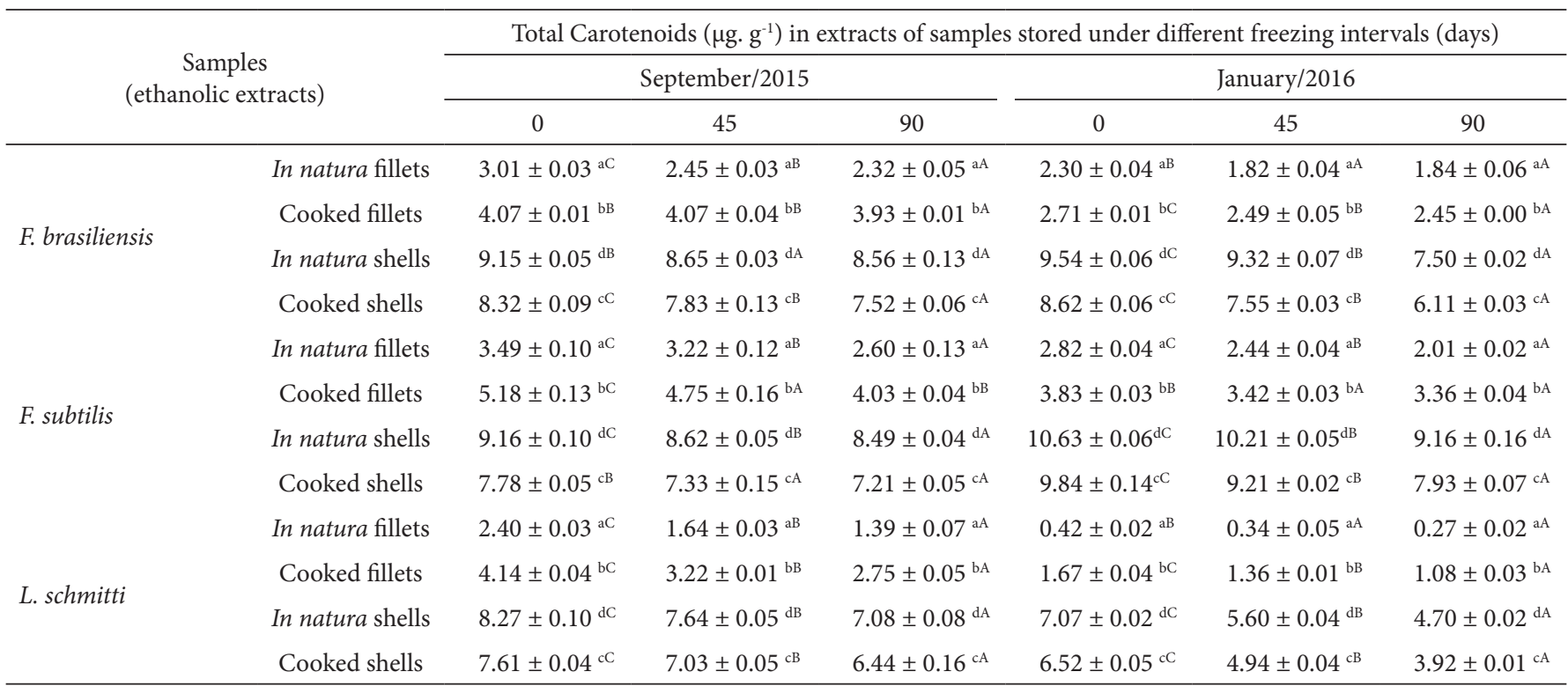

Averages of data from the same period (i.e. September/2015 or January/2016) and shrimp species, followed by the same lowercase letters in the same column, or the same uppercase letters in the same row, do not differ statistically at the $5 \%$ level by the Tukey test $(\rho<0.05)$.

2016. For cooked L. schmitti shells, the percentual reductions of carotenoids were about 8-9 (2015) and 9-16\% (2016).

The findings that shells of the white and pink shrimps of the Brazilian tropical coast are their major reservoir of carotenoids, and that heat-treatment reduce significantly such contents, agree to our previous studies of carotenoids in L. schmitti (Lira et al., 2017).

Carotenoids are mainly supplied to shrimps by algae ingestion, being essential for communication and reproduction, since shrimps accumulated them in their carapace for attraction, warning, and camouflage (Mezzomo \& Ferreira, 2016). Although this, their contents detected in the crushed shells of the three species studied were lower than those detected by Sowmya \& Sachindra (2012), in acetone-extracts of Penaeus indicus shells $\left(47.86 \mu \mathrm{g} \mathrm{g}^{-1}\right)$, or by Seabra et al. (2014), in hexane: isopropanol extracts of the L. vannamei shells $\left(42.74 \pm 1.75 \mu \mathrm{g} \mathrm{g}^{-1}\right)$.

Dalei \& Sahoo (2015), however, showed that although ethanolic-extracts of shrimps have $40 \%$ less carotenoids than the acetone or other non-polar solvents ones, the $\mathrm{AA} \%$ of the ethanolic extracts is greater. Polar solvents are generally good extractors for xanthophylls (polar carotenoids) such as astaxanthin, whereas less polar solvents are good for carotenes such as $\alpha$ or $\beta$-carotenes, and non-polar solvents are not recommended, as their penetration through the hydrophobic mass surrounding the pigments is limited, and most of them do not comply with regulations for human consumption or environmental laws. But pure or $92-95 \%$ ethanol are efficient and compatible for the extraction of carotenes and xanthophylls, so that shells of shrimps may be a great source of natural carotenoids ethanolic extraction and the discard of final solid and liquid residues do not become an environmental problem (Kale et al., 2007).

Also, studies of Seabra et al. (2014) on the TC of shells of L. vannamei stored for 0-180 days under freezing (in polyethylene packages, at $\left.-28.3^{\circ} \mathrm{C} \pm 3.8\right)$, and then, homogenized with hexane: isopropanol $(60: 40 \mathrm{v} / \mathrm{v})$, showed a significant reduction $(\rho<0.05)$ in such contents along the time.

Due to the high unsaturation rate, several factors cause isomerization of carotenoids from the most natural stable form (trans) to the cis-form, promoting a slight loss of color and provitamin activity. The mentioned oxidation depends of the carotenoid structure, as well as the availability of oxygen, enzymes, metals, acids, prooxidants and antioxidants, and of high temperatures and light exposure (Mezzomo \& Ferreira, 2016). The stability is protected and preserved during freezing only if all oxygen and light are excluded. However, slow thawing and the presence of some oxygen, even when samples are stored in aseptic plastic bags at $-10^{\circ} \mathrm{C}$, turn the carotenoids still susceptible to oxidation and isomerization, leading the formation of epoxy-carotenoids and apocarotenoids (Rodriguez-Amaya, 2004; Harrison \& Quadro, 2018). This reduces coloration and forms volatile compounds with unpleasant smell. Therefore, since the stability of carotenoids in the shrimps depends on several factors, such as their chemical structures (polarity, etc.), types of samples reservoirs (fillets or shells), packing as well as storage period, freezing temperature and/or even luminosity (in the present study, the freezing was carried out under total dark), the decay of TC during the freezing-storage may be due to the oxygen presence in the packages kept for 45,90 days under freezing, or even to their slow thawing at room temperature before analysis. 


\subsection{Percentage of Antioxidant activity (AA\%) of fillets and shells}

The Table 2 shows the AA\% (DPPH test) in the ethanolic extracts from fillets and shells of the three studied shrimps. There was a strong correlation between AA\% and carotenoids contents (Table 1), so that the $\mathrm{AA} \%$ in extracts of cooked fillets significantly increased in relation to the non-cooked ones $(\rho<0.05)$, and the AA\% of the shells extracts significantly decreased after such heat treatment $(\rho<0.05)$. Likewise, the highest AA\% for fillets and shells at time "zero" were found in F. subtilis (respectively 58.82 and $84.54 \%$ in 2015 , and 80.27 and $91.53 \%$ in 2016). In addition, over the time of storage under freezing, AA\% decreased significantly in all the extracts $(\rho<0.05)$, being the decay also more accentuated in F. subtilis samples (26-46\% of reduction).

\subsection{Identification of the carotenoids present on the ethanolic extracts}

The detection of different types of carotenoid in the ethanolic extracts was preliminary analyzed with low cost methodologies, such as thin layer chromatography (TLC) and UV-visible scanning spectrophotometry from 300 to $600 \mathrm{~nm}$. Then, the Table 3 illustrates the TLC profile of ethanolic extracts of the time "zero" in natura and cooked fillets and shells of the studied shrimps, collected in January 2016, as well as the chromatographic profile of the chosen standards.

The chromatogram of the extracts of fillets of F. brasiliensis showed only one band with Rf 0.33 , whereas the extracts of this shrimp shells had four bands with Rf $0.33,0.48,0.74$ and 0.83 . Extracts of F. subtilis shells showed four bands (0.33, 0.50, 0.75 and 0.85 ), while extracts of their fillets showed only the first three bands.

The chromatogram of the extracts of $L$. schmitti fillets, on the other hand, had no bands, while the extracts of the shells of this shrimp showed only two bands of low intensity color ( Rf 0.50 and 0.75). Comparing such findings to the "Carotenoid TLC/C system NatuRose ${ }^{\mathrm{TM}}$ " of Lorenz (1998), it is possible to infer that

Table 2. Percentage of Antioxidant Activity (AA\%) in ethanolic extracts from fillet and shells of pink (Farfantepenaeus brasiliensis and F. subtilis) and white (Litopenaeus schmitti) shrimps (in natura or cooked) samples, analyzed immediately after acquisition and treatment (time "zero") or after storing under different freezing intervals (45 and 90 days).

\begin{tabular}{|c|c|c|c|c|c|c|c|}
\hline \multirow{3}{*}{\multicolumn{2}{|c|}{$\begin{array}{c}\text { Samples } \\
\text { (ethanolic extracts) }\end{array}$}} & \multicolumn{6}{|c|}{ AA\% in extracts of samples stored under different freezing intervals (days) } \\
\hline & & \multicolumn{3}{|c|}{ September/2015 } & \multicolumn{3}{|c|}{ January/2016 } \\
\hline & & 0 & 45 & 90 & 0 & 45 & 90 \\
\hline \multirow{2}{*}{ F. brasiliensis } & Cooked fillets & $59.61 \pm 1.01 \mathrm{bC}$ & $54.83 \pm 0.17$ ьв & $43.01 \pm 0.82^{\mathrm{bA}}$ & $66.98 \pm 0.10^{\mathrm{bC}}$ & $57.69 \pm 1.10^{\text {bв }}$ & $40.43 \pm 0.27^{\mathrm{bA}}$ \\
\hline & In natura shells & $78.83 \pm 0.45^{\mathrm{cC}}$ & $77.18 \pm 0.18 \mathrm{~dB}$ & $48.52 \pm 1.03 \mathrm{dA}$ & $77.19 \pm 0.31^{\mathrm{cC}}$ & $59.49 \pm 0.49^{\mathrm{cbB}}$ & $47.05 \pm 0.15^{\mathrm{cA}}$ \\
\hline \multirow{4}{*}{ F. subtilis } & In natura fillets & $58.82 \pm 0.65^{\mathrm{aC}}$ & $41.53 \pm 0.39$ ав & $38.44 \pm 0.29^{\mathrm{aA}}$ & $80.27 \pm 0.55^{\mathrm{aC}}$ & $48.48 \pm 1.17^{\mathrm{aB}}$ & $43.50 \pm 0.71^{\mathrm{aA}}$ \\
\hline & Cooked fillets & $71.95 \pm 1.61^{\mathrm{bC}}$ & $53.73 \pm 1.09^{\text {вв }}$ & $52.75 \pm 1.00^{\mathrm{bA}}$ & $86.00 \pm 1.10^{\mathrm{bC}}$ & $58.85 \pm 0.18^{\text {bв }}$ & $53.13 \pm 2.39^{\mathrm{bA}}$ \\
\hline & In natura shells & $84.54 \pm 0.47 \mathrm{dC}$ & $72.39 \pm 0.17 \mathrm{~dB}$ & $54.83 \pm 0.17 \mathrm{dA}$ & $91.53 \pm 0.83^{\mathrm{dC}}$ & $67.89 \pm 0.65^{\mathrm{cB}}$ & $59.21 \pm 0.46^{\mathrm{dA}}$ \\
\hline & Cooked shells & $78.73 \pm 0.67^{c C}$ & $56.94 \pm 0.88^{\mathrm{cB}}$ & $49.66 \pm 1.40^{\mathrm{cA}}$ & $89.33 \pm 0.00^{\mathrm{cC}}$ & $59.30 \pm 0.77^{\text {ьв }}$ & $56.80 \pm 0.90^{\mathrm{cA}}$ \\
\hline L. schmitti & Cooked shells & $78.64 \pm 0.00^{c C}$ & $76.83 \pm 0.45^{\text {ьв }}$ & $72.17 \pm 1.50^{\mathrm{cA}}$ & $75.84 \pm 0.83^{\mathrm{cC}}$ & $69.03 \pm 0.37^{\mathrm{cB}}$ & $53.84 \pm 1.47^{\mathrm{cA}}$ \\
\hline
\end{tabular}

Averages of data from the same period (i.e. September/2015 or January/2016) and shrimp species, followed by the same lowercase letters in the same column, or the same uppercase letters in the same row, do not differ statistically at the $5 \%$ level by the Tukey test $(\rho<0.05)$.

Table 3. Thin layer chromatography (TLC, silica gel 60F $\mathrm{F}_{254 \mathrm{~nm}}$ Merck) of carotenoids extracted from fillets (A,B) and shells (C,D), in natura (A,C) and cooked (B,D), of the pink (Farfantepenaeus brasiliensis and F. subtilis) and white (Litopenaeus schmitti) shrimps, harvested in January/2016 in the coast of Maceió-Alagoas/Brazil. The solvent system (mobile phase) was acetone: hexane (25:75 v/v).

\begin{tabular}{|c|c|c|c|c|c|c|c|c|c|c|c|c|c|c|c|}
\hline \multicolumn{4}{|c|}{ Farfantepenaeus brasiliensis } & \multicolumn{4}{|c|}{ F. schmitti } & \multicolumn{4}{|c|}{ Litopenaeus schmitti } & \multicolumn{2}{|c|}{ Standards } & \multirow{2}{*}{$\mathrm{R}_{\mathrm{f}}$} & \multirow{2}{*}{ Color } \\
\hline A & B & $\mathrm{C}$ & $\mathrm{D}$ & A & B & $\mathrm{C}$ & $\mathrm{D}$ & A & B & $\mathrm{C}$ & $\mathrm{D}$ & Ast & $\beta$-car & & \\
\hline- & - & + & + & - & - & + & + & - & - & - & - & - & +++ & $0.83 / 0.85$ & Golden yellow \\
\hline- & - & + & + & + & + & + & + & - & - & + & + & ++ & - & 0.74 & orange \\
\hline- & - & ++ & ++ & + & + & ++ & ++ & - & - & ++ & ++ & +++ & - & 0.48 & orange \\
\hline+ & + & + & + & + & + & + & + & - & - & - & - & + & - & 0.33 & orange \\
\hline
\end{tabular}

Ast $=$ standard astaxanthin; $\beta$-car $=$ standard $\beta$-carotene; $\mathrm{R}_{\mathrm{f}}=$ retention factor. 
the orange band of $\mathrm{Rf} 0.33$ corresponds to free astaxanthin in this solvent system, while for astaxanthin monoester the Rf was 0.48 (instead of 0.50 ), and for astaxanthin diester it was 0.74 (instead of 0.75 ). The Rf for $\beta$-carotene in the solvent used by Lorenz (1998) was 0.99 , but in the ethanolic extract it was 0.83-0.85. Therefore, the results of the analysis of TLC indicate that the carotenoids found in larger amount in the studied shrimps are the free astaxanthin, and the monoester and diester astaxanthins, being the last ones the only detected in ethanolic extracts of L. schmitti at "zero" shells in "time zero", what could explain the higher carotenoid content and antioxidant activity of these extracts in relation to the ones of fillets from the same shrimp, and this probably explain also the white-greyish aspect of the fresh L. schmitii (Figure 2).

According to Silva (2010), 75\% of the TC found in marine shrimps is astaxanthin (in free and stereotactic form). Its high antioxidant potential is based on its molecular structure (Armenta \& Guerrero-Legarreta, 2009), once it may sequester singlet oxygen because of their numerous conjugated double bonds. This antioxidant action is based on the breaking of the free radical by the donation of a hydrogen atom of the hydroxyl and phenolic groups (Hernández Becerra et al., 2014), and as other carotenoids, it forms stable products unable of propagating oxidation reactions in series.

Regarding to the UV-visible scanning spectrophotometry $(300-600 \mathrm{~nm})$ analysis of all the ethanolic extracts of the fillet and shells of the three studied shrimps, they showed the same wavelength picks of absorption light, typical for carotenoids such as astaxanthin and $\beta$-carotene. As an example, the Figure 3 shows the spectra for samples of F. subtilis, in which the maximum absorption for the extract of shells occurs at $472 \mathrm{~nm}$, and the maximum absorption for the extract of fillets shows two bands, one at 472 and other at $427 \mathrm{~nm}$. According to the literature, astaxanthin in ethanol shows a maximum absorption length of $472 \mathrm{~nm}$, whilst $\beta$-carotene has a shoulder (Johnson \& An, 1991). However, once the studied ethanolic extracts contain other carotenoids, it is possible that occurred a bathochromic displacement in the spectrum of the extract of fillets.

\subsection{Microbiological quality of the shrimp samples and identification of bacteria}

None of the samples of the different parts of the species of shrimps, in natura or cooked, at time "zero" or after 90 days stored under freezing, from both harvests (2015 and 2016) were contaminated by histaminogenic bacteria. However, after $48 \mathrm{~h}$ of incubation of samples harvested in September of 2015, the fresh and cooked samples of the three studied species of shrimps presented bacterial colonies growth, although their counts were lower than those of samples under freezing for 90 days (Table 4). The maximum population from the samples in natura at time "zero" was $3.14 \log _{10}$ CFU g ${ }^{-1}$ of L. schmitti shells, and $2.02 \log _{10}$ $\mathrm{CFU} \mathrm{g}{ }^{-1}$ of $F$. brasiliensis fillets.

The analysis of variance showed that the freezing time influenced the growth of bacteria in the "in natura" samples of fillets and shells $(\rho<0.05)$ of shrimps harvested in this first season, and according to the Tukey's test ( $5 \%$ of significance), the number of bacterial colonies found in fillet samples was not statistically different between the studied species. After 90 days of freezing, the number of CFUs found in the fillet samples (September 2015) was more accentuated than at the time "zero", being statistically superior in F. brasiliensis than in the other two studied species. On the other hand, when the shells samples were analyzed, the F. subtilis samples presented lower contamination (CFU values) than those of F. brasiliensis and L. schmitti.

Regarding the harvest of January 2016 (Table 4), the contamination of fillet and shells was influenced by the species and interval under freezing $(\rho<0.05)$. At the time "zero", the number of $\log _{10} \mathrm{CFU} \mathrm{g}^{-1}$ in fillets and shells in natura were statistically similar among the species F. subtilis and L. schmitti (respectively $\cong 3.82 \log _{10} \mathrm{CFU} \mathrm{g}^{-1}$ and $\cong 4.13 \log _{10} \mathrm{CFU} \mathrm{g}^{-1}$ ), and different from the samples of $F$. brasiliensis, but after 90 days under freezing, the contamination on these samples were reduced more intensively in L. schmitti and slightly increased in F. brasiliensis.

Cooked samples from time "zero" (January 2016) had different degrees of contamination, it means, only F. subtilis showed more counts of bacteria, and samples of this species stored 90 days under freezing did not show any bacterial growth, while the cooked fillets of other species showed none (F. brasiliensis) or a very low number (L. schmitti) of $\log _{10} \mathrm{CFU} \mathrm{g}{ }^{-1}$. Cooked shells of the three species stored under freezing for 90 days, however, showed a reduction in the contamination of $L$. schmitti and an increasing in the number of bacterial cells in F. brasiliensis.

Yokoyama (2007) and Economou et al. (2007) reported that freezing storage interval associated to endogenous temperature, influence the microbial development in fishes. In none of the cases, however, the total number of bacteria of samples exceeded the maximum tolerable limits for frozen or cooked crustacean food recommended by the International Commission on Microbiological Specifications for Foods (2016) and by the Brazilian Resolution ANVISA-RDC n ${ }^{\circ} 12 / 2001$, it means, 5.0-7.0 $\log _{10} \mathrm{CFU} \mathrm{g}^{-1}$ [when the analysis is specific for thermotolerant or not coliforms, Salmonella sp., Staphylococcus coagulase positive or not, and the total number of presumptive

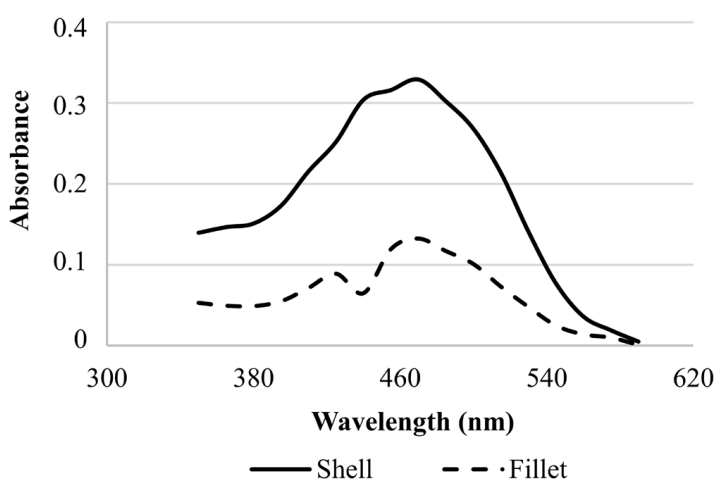

Figure 3. Spectrum of light absorption of the ethanolic extracts of the in natura shells and fillets of the shrimp Farfantepenaeus subtilis, obtained immediately after harvest and transport to the laboratory (time "zero"). The profile was the same for extracts of cooked shells and fillets, and even for the different shrimps, and the differences were in the intensity of absorbance. 
Table 4. Bacterial colony forming units (CFU) in fillets and shells samples (in natura and after heat treatment) of the shrimps F. brasiliensis, F. subtilis and L. schmitti, harvested in September 2015 and January 2016 on the coast of Maceió-AL (after 48 h of incubation at $35 \pm 1{ }^{\circ} \mathrm{C}$, dark).

\begin{tabular}{|c|c|c|c|c|}
\hline \multirow[b]{2}{*}{ Shrimp Species } & \multicolumn{4}{|c|}{ September 2015} \\
\hline & \multicolumn{2}{|c|}{$\begin{array}{l}\text { In natura Fillets }\left(\log _{10} \mathrm{CFU} \mathrm{g}^{-1}\right) \\
\text { Storage time (days) }\end{array}$} & \multicolumn{2}{|c|}{$\begin{array}{l}\text { Cooked Fillets }\left(\log _{10} \mathrm{CFU} \mathrm{g}^{-1}\right) \\
\text { Storage time (days) }\end{array}$} \\
\hline F. brasiliensis & $2.02 \pm 0.17$ ьв & $3.74 \pm 0.01 \mathrm{bC}$ & $0.00 \pm 0.00^{\mathrm{aA}}$ & $3.92 \pm 0.02 \mathrm{bD}$ \\
\hline F. subtilis & $0.00 \pm 0.00 \mathrm{aA}$ & $3.67 \pm 0.02 \mathrm{aC}$ & $2.91 \pm 0.03$ ьв & $3.99 \pm 0.01 \mathrm{bD}$ \\
\hline \multirow[t]{2}{*}{ Shrimp Species } & \multicolumn{2}{|c|}{$\begin{array}{c}\text { In natura Shells }\left(\log _{10} \mathrm{CFU} \mathrm{g}^{-1}\right) \\
\text { Storage time (days) }\end{array}$} & \multicolumn{2}{|c|}{$\begin{array}{l}\text { Cooked Shells }\left(\log _{10} \mathrm{CFU} \mathrm{g}^{-1}\right) \\
\text { Storage time (days) }\end{array}$} \\
\hline & 0 & 90 & 0 & 90 \\
\hline F. brasiliensis & $3.06 \pm 0.06^{\mathrm{bC}}$ & $3.00 \pm 0.04^{\mathrm{bC}}$ & $2.34 \pm 0.10^{\mathrm{aA}}$ & $2.91 \pm 0.09^{a \mathrm{~B}}$ \\
\hline F. subtilis & $1.28 \pm 1.11^{\mathrm{aA}}$ & $3.16 \pm 0.05^{\mathrm{cC}}$ & $2.61 \pm 0.09^{\text {вв }}$ & $3.62 \pm 0.02^{\mathrm{cD}}$ \\
\hline \multirow[t]{2}{*}{ Shrimp Species } & \multicolumn{2}{|c|}{$\begin{array}{l}\text { In natura Fillets }\left(\log _{10} \mathrm{CFU} \mathrm{g}^{-1}\right) \\
\text { Storage time (days) }\end{array}$} & \multicolumn{2}{|c|}{$\begin{array}{l}\text { Cooked Fillets }\left(\log _{10} \mathrm{CFU} \mathrm{g}^{-1}\right) \\
\text { Storage time (days) }\end{array}$} \\
\hline & 0 & 90 & 0 & 90 \\
\hline F. brasiliensis & $3.34 \pm 0.01 \mathrm{aC}$ & $3.31 \pm 0.05^{b C}$ & $2.02 \pm 0.17 \mathrm{aB}$ & $0.00 \pm 0.00^{\mathrm{aA}}$ \\
\hline F. subtilis & $3.80 \pm 0.01^{\mathrm{bC}}$ & $3.25 \pm 0.03^{\mathrm{bB}}$ & $3.98 \pm 0.01^{\mathrm{cC}}$ & $0.00 \pm 0.00^{\mathrm{bA}}$ \\
\hline L. schmitti & $3.82 \pm 0.04^{\mathrm{bC}}$ & $2.97 \pm 0.02^{\mathrm{aB}}$ & $2.95 \pm 0.02^{\text {ьв }}$ & $2.12 \pm 0.17^{\mathrm{aA}}$ \\
\hline \multirow[t]{2}{*}{ Shrimp Species } & \multicolumn{2}{|c|}{$\begin{array}{c}\text { In natura Shells }\left(\log _{10} \mathrm{CFU} \mathrm{g}^{-1}\right) \\
\text { Storage time (days) }\end{array}$} & \multicolumn{2}{|c|}{$\begin{array}{c}\text { Cooked Shells }\left(\log _{10} \mathrm{CFU} \mathrm{g}^{-1}\right) \\
\text { Storage time (days) }\end{array}$} \\
\hline & 0 & 90 & 0 & 90 \\
\hline F. brasiliensis & $2.34 \pm 0.10^{\text {aA }}$ & $2.93 \pm 0.05^{\mathrm{aB}}$ & $3.12 \pm 0.03^{\mathrm{aC}}$ & $3.26 \pm 0.00 \mathrm{aD}$ \\
\hline
\end{tabular}

Averages of data followed by the same lowercase letters in the same column, or the same uppercase letters in the same row, do not differ statistically at the $5 \%$ level by the Tukey test $(\rho<0.05$ ).

mesophilic bacteria (more probable number of bacteria), in view of its density in lauryl sulfate tryptose broth, with a composition and $\mathrm{pH}$ adequate to general microbial growth, but this was not the case of the present work, as the counted bacteria grew in common Niven Agar but not in the modified Niven broth, specific to histaminogenic bacteria] (Brasil, 2001).

According to Andrade et al. (2008), tropical fishes/crustaceans have smaller amount of psychrophilic microorganisms than those from temperate sites, and the absence of histaminogenic bacteria may be an indication that harvesting and marketing are under adequate conditions of hygiene and temperature, and they can be stored under freezing to extend their shelf life. However, although in non-alarming numbers, all the five Gram+ non histaminogenic rods that grew in Agar Niven were biochemically identified as species of Corynebacterium (strain FBCA), Listeria (strain FBCI), Bacillus (strain LSCI), Arthrobacter (strain FBFI) and Erysipelothrix (strain LSCA).

The strains of Corynebacterium (FBCA) and Bacillus (LSCI) produced extracellular proteases, lipases and amylases, being able to reduce trimethylamine oxide to trimethylamine, it means, produced off bad smells volatile compounds. According to
Alibi et al. (2016), the bacteria of this genus Corynebacterium are a group of thermotolerant short pleomorphic rods, immobile and non-sporulating, belonging to the Actinobacteria class, and they are distributed in a wide range of environments such as soil, water, plants surface, and some of them are even pathogenic to animals and man. Bacillus, on the other hand, is a genus associated to occurrences of food poisoning, and in 1950 some species were recognized as the cause of foodborne disease (Jay, 2005), with high resistance to different extreme environmental conditions (temperature, $\mathrm{pH}$, radiation, low humidity, etc.), persisting viable for months through their spores.

Buller (2014) also reported the isolation of strains of Corynebacterium and Bacillus from apparently healthy shrimps, but not from diseased ones, and Budzińska et al. (2012) described that the genus Listeria also has a worldwide geographical distribution, from land to water, being often isolated from soil, faeces, decaying or not plant material, silage, treated household and industrial/agro-industrial (meat/crops) sewage. Contaminated sewage plays an essential role in transmission of Listeria in aqueous environments, which consequently can be a cause of their presence in aquatic animals. It has been 
isolated since the 1980s, on a regular basis, in fresh and frozen shrimps, and even in the lightly preserved and ready-to-eat shrimp products, indicating that the existing practices used by the manufacturers or processors are insufficient to eliminate the pathogen (Wan Norhana et al., 2010).

The fourth strain isolated was the Gram+ aerobic rod biochemically identified as a species of Arthrobacter (FBFI), a genus metabolically versatile, producer of many different enzymes that allows it to develop in a wide range of substrates and environments. Finally, the last isolated bacteria was a species of Erysipelothrix (LSCA), being a small pleomorphic Gram+ immobile rod, forming short to long chains (long filaments). This genus is widely distributed throughout nature, in soil or wherever nitrogenous substances are decomposing, as a saprophyte, and some are commonly found in the digestive tract of birds and mammals or in the surface of some types of fish and crustacean, and eventually are the causative agents of human erysipeloid, which is generally an occupational infection. (Stackebrandt et al., 2006; Suseela et al., 2015).

The discrete presence of such microorganisms may be related to handling of the crustaceans during harvest, sale or to the casual contamination of washing water/ice - by fishermen, domestic animals and sewage discarded in the marine waters. The bacteria detected are not even mentioned in the legislation to control the quality and healthy risks of crustacean and frozen foods, but it alerts for the constant need to seek improvements in the quality of fishery products, such as frequent training of staff working in this sector (fishing, industry and market), in good manufacturing practices, standard procedures for sanitation, and hazard and critical point analysis of control.

\section{Conclusions}

Instead of being discarded as a pollutant in the environment, shells of the shrimps F. brasiliensis, F. subtilis and Litopenaeus schmitti, from the coast of Alagoas, constitute excellent source of carotenoids, specially the powerful antioxidant astaxanthin. This carotenoid content decreases when the samples (shells and fillets) are stored under freezing for 45 and 90 days. Cooking increase significantly the efficiency of extraction of these carotenoids in fillets, whilst in the shells such differences are not so pronounced, once prior to heating the carotenoids in the fillets are complexed with proteins. The shell and fillet of raw shrimp have high AA, however, cooking slightly reduces it in shells and increases it in fillets. Storage under freezing for 90 days also reduce the TC and the AA\% of the ethanolic extracts of the different samples of shrimps, probably because of the rupture of the stability of carotenoids or carotene-proteins by molecular oxygen, etc. Samples collected in September/2015 presented |TC and AA\% slightly different from those obtained in January/2016, proving that seasonality influences on nutritional quality of shrimps, especially because of carotenoids composition depends of the availability and diversity of the algae in the environment. Thin layer chromatography was a simple, fast, efficient, and low-cost technique used to partially separate and identify the carotenoids present in the samples, especially when the Rf obtained for each separated band could be associated with UV-visible spectroscopy spectrum of the extracts. Only 5 bacteria (Corynebacterium sp.,
Listeria sp., Arthrobacter sp., Bacillus sp. and Erysipelothrix sp.) were isolated from the shrimp studied, but none was producer of biogenic amines, neither grew in a concentration considered as a healthy risk alarming by the legislation. Although this, is always important to recommend aseptic-sanitary conditions during capture, handling, transporting and package of shrimps, as well as for the quality of the water and ice used for conservation during the marketing, avoiding dangerous contamination.

\section{Acknowledgements}

This work was supported by "Brazilian National Council for Science and Technology" (CNPq), "Brazilian Foundation for Improvement of Higher-Level Personnel" (CAPES) and the private company "S.A. Usina Coruripe de Açúcar e Álcool" (Coruripe-Al/Brazil).

\section{References}

Alibi, S., Ferjani, A., \& Boukadida, J. (2016). Implication of Corynebacterium species in food's contamination. Journal of Coastal Life Medicine, 4(5), 416-419. http://dx.doi.org/10.12980/jclm.4.2016J6-26.

An, Z., Zhang, Y., \& Sun, L. (2018). Effects of dietary astaxanthin supplementation on energy budget and bioaccumulation in Procambarus clarki (Girard, 1852) crayfish under microcystin-LR stress. Toxins, 10(7), 277. http://dx.doi.org/10.3390/toxins10070277. PMid:29973494.

Andrade, C. S., Druzian, J. L., Leite, C. C., Carvalho Filho, C. D., Miranda, M. P. S., Macêdo, C. S., \& Guimarães, A. G. (2008). Determinação da microbiota histamina positiva em camarão. Revista do Instituto Adolfo Lutz (Print), 67(1), 46-51. Retrieved from: http:// periodicos.ses.sp.bvs.br/scielo.php?script=sci_arttext\&pid=S007398552008000100005\&lng=en\&tlng=pt

Armenta, R. E., \& Guerrero-Legarreta, I. (2009). Stability studies on astaxanthin extracted from fermented shrimp byoproducts. Journal of Agricultural and Food Chemistry, 57(14), 6095-6100. http://dx.doi. org/10.1021/jf901083d. PMid:19548684.

Arvayo-Enríquez, H., Mondaca-Fernández, I., Gortárez-Moroyoqui, P., López-Cervantes, J., \& Rodríguez-Ramírez, R. (2013). Carotenoids extraction and quantification: a review. Analytical Methods, 5(12), 2916-2924. http://dx.doi.org/10.1039/c3ay26295b.

Bose, K. S., \& Agrawal, B. K. (2007). Effect of lycopene from tomatoes (cooked) on plasma antioxidant enzymes, lipid peroxidation rate and lipid profile in grade-I hypertension. Annals of Nutrition \& Metabolism, 51(5), 477-481. http://dx.doi.org/10.1159/000111170. PMid:18025823.

Brasil, Ministério da Agricultura, Pecuária e Abastecimento. (2003, September 18). Oficializa os métodos analíticos oficiais para análises microbiológicas para controle de produtos de origem animal e água (Instrução normativa ${ }^{\circ}$ 62, de 26 de agosto de 2003). Diário Oficial [da] República Federativa do Brasil.

Brasil, Ministério da Saúde. (2001, January 10). Aprova o regulamento técnico sobre padrões microbiológicos para alimentos (Resolução RDC $n^{\circ} 12$, de 2 de janeiro de 2001). Diário Oficial [da] República Federativa do Brasil, seção 1.

Budzińska, K., Szejniuk, B., \& Wroński, G. (2012). Survival time of bacteria Listeria monocytogenes in water environment and sewage. Polish Journal of Environmental Studies, 21(1), 31-37. 
Buller, N. B. (2014). Bacteria and fungi from fish and other aquatic animals: a practical identification manual (2nd ed., 919 p.). Wallingford: CABI-Science.

Cavalcanti, A. S. R. R. M., Rosa, M. E. C., Cavalcanti, C., \& Lisboa, H. M. (2016). Seasonality study of Penaeus vannamei shrimp shells from aquaculture. Revista Brasileira de Produtos Agroindustriais, 18(esp), 487-493. http://dx.doi.org/10.15871/1517-8595/rbpa. v18nespp487-493.

Chandrasekaran, M., Lakshmanaperumalsamy, P., \& Chandramohan, D. (1985). Fish flesh agar medium - a suitable experimental medium for the detection of spoilage bacteria. Antonie van Leeuwenhoek, 51(2), 219-225. http://dx.doi.org/10.1007/BF02310014. PMid:4037785.

Cruz, C. D. G. (2013). A software package for analysis in experimental statistics and quantitative genetics. Acta Scientiarum, 35, 271-276.

Cullimore, D. R. (2019). Practical atlas for bacterial identification (2nd ed., 327 p.). Boca Raton: CRC Press.

Dalei, J., \& Sahoo, D. (2015). Extraction and characterization of astaxanthin from the crustacean shell waste from shrimp processing industries. International Journal of Pharmaceutical Sciences and Research, 6(6), 2532-2537.

Dias, A. M., \& Ferreira, M. L. S. (2015). Separação de carotenoides, clorofilas e flavonoides em folhas de plantas: uma abordagem simples e ecológica. Química e Ensino, 138, 57-62.

Economou, V., Brett, M. M., Papadopoulou, C., Frillingos, S., \& Nichols, T. (2007). Changes in histamine and microbiological analyses in fresh and frozen tuna muscle during temperature abuse. Food Additives and Contaminants, 24(8), 820-832. http://dx.doi. org/10.1080/02652030701278321. PMid:17613069.

Eliassen, A. H., Liao, X., Rosner, B., Tamimi, R. M., Tworoger, S. S., \& Hankinson, S. E. (2015). Plasma carotenoids and risk of breast cancer over 20 years of follow-up. The American Journal of Clinical Nutrition, 101(6), 1197-1205. http://dx.doi.org/10.3945/ ajcn.114.105080. PMid:25877493.

Food and Agriculture Organization - FAO. (2015). Weak market prices persist in 2015 but import demand remains disappointing. Rome. Retrieved from http://www.fao.org/in-action/globefish/marketreports/resource-detail/en/c/357932/

Harrison, E. H., \& Quadro, L. (2018). Apocarotenoids: emerging roles in mammals. Annual Review of Nutrition, 38(1), 153-172. http:// dx.doi.org/10.1146/annurev-nutr-082117-051841. PMid:29751734.

He, L., Zhang, R., \& Zhang, R. (2017). Study on the extraction of astaxanthin from prawn. Journal of Ningde Normal University, 29, 184-188.

Hernández Becerra, J. A., Ochoa Flores, A. A., Valerio-Alfaro, G., SotoRodriguez, I., Rodríguez-Estrada, M. T., \& García, H. S. (2014). Cholesterol oxidation and astaxanthin degradation in shrimp during sun drying and storage. Food Chemistry, 145, 832-839. http://dx.doi. org/10.1016/j.foodchem.2013.08.098. PMid:24128553.

International Commission on Microbiological Specifications for Foods - ICMSF. (2016). Use of data for assessing process control and product acceptance (Microorganisms in Foods, No. 8). New York: Springer Science.

Jay, J. M. (2005). Microbiologia dos alimentos (711 p.). Porto Alegre: Artmed.

Je, J. Y., Park, P.-J., Kim, E.-K., \& Ahn, C.-B. (2009). Antioxidant and angiotensin I converting enzyme inhibitory activity of Bambusae caulis in Liquamen. Food Chemistry, 113(4), 932-935. http://dx.doi. org/10.1016/j.foodchem.2008.08.022.
Johnson, E. A., \& An, G. H. (1991). Astaxanthin from microbial sources. Critical Reviews in Biotechnology, 11(4), 297-326. http://dx.doi. org/10.3109/07388559109040622.

Kale, A., Zhu, F., \& Cheryan, M. (2007). Separation of high-value products from ethanol extracts of corn by chromatography. Industrial Crops and Products, 26(1), 44-53. http://dx.doi.org/10.1016/j. indcrop.2007.01.006.

Lira, G. M., Lopez, A. M. Q., Firmino, G. O., Santos, S. D., \& Bezerra, R. S. (2017). Total carotenoids and antioxidant activity of fillets and shells (in natura or cooked) of "Vila Franca" shrimp (Litopenaeus schmitti) in different intervals of storage under freezing. Ciência e Agrotecnologia, 41(1), 94-103. http://dx.doi.org/10.1590/141370542017411023616 .

Lorenz, T.R. (1998). Thin layer chromatography (TLC) system for NatuRoseTM Carotenoids. Retrieved from http://www.ruscom.com/ cyan/web02/pdfs/naturose/axbul3.pdf

Maan, M. E., \& Sefc, K. M. (2013). Colour variation in cichlid fish: developmental mechanisms, selective pressures and evolutionary consequences. Seminars in Cell \& Developmental Biology, 24(6-7), 516528. http://dx.doi.org/10.1016/j.semcdb.2013.05.003. PMid:23665150.

Mavromatis, P., \& Quantick, P. (2002). Modification of Niven's Medium for enumeration of histamine-forming bacteria and discussion of the parameters associated with its use. Journal of Food Protection, 65(3), 546-551. http://dx.doi.org/10.4315/0362-028X-65.3.546. PMid:11899055.

McCall, B., McPartland, C. K., Moore, R., Frank-Kamenetskii, A., \& Booth, B. W. (2018). Effects of astaxanthin on the proliferation and migration of breast cancer cells in vitro. Antioxidants, 7(10), 135. http://dx.doi.org/10.3390/antiox7100135. PMid:30287735.

Mezzomo, N., \& Ferreira, S. R. S. (2016). Carotenoids functionality, sources, and processing by supercritical technology: a review. Journal of Chemistry, 7, 1-16. http://dx.doi.org/10.1155/2016/3164312.

Moran, N. A., \& Jarvik, T. (2010). Lateral transfer of genes from fungi underlies carotenoid production in aphids. Science, 328(5978), 624627. http://dx.doi.org/10.1126/science.1187113. PMid:20431015.

Nucera, D., Maddox, C. W., Hoien-Dalen, P., \& Weigel, R. M. (2006). Comparison of API 20E and invA PCR for Identification of Salmonella enterica isolates from swine production units. Journal of Clinical Microbiology, 44(9), 3388-3390. http://dx.doi.org/10.1128/ JCM.00972-06. PMid:16954281.

Okada, S., Nur-E-Borhan, S. A., \& Yamaguchi, K. Y. (1994). Carotenoid composition in the exoskeleton of commercial black tiger prawn. Fisheries Science, 60(2), 213-215. http://dx.doi.org/10.2331/fishsci.60.213.

Pedrosa, L. F. C., \& Cozzolino, S. M. F. (2001). Composição centesimal e de minerais de mariscos crus e cozidos da cidade de Natal/RN. Food Science and Technology, 21(2), 154-157. http://dx.doi.org/10.1590/ S0101-20612001000200006.

Rao, A. R., Ravishankar, G. A., \& Sarada, R. (2012). Cultivation of green alga Botryococcus braunii in raceway, circular ponds under outdoor conditions and its growth, hydrocarbon production. Bioresource Technology, 123, 528-533. http://dx.doi.org/10.1016/j. biortech.2012.07.009. PMid:22940364.

Rodriguez-Amaya, D. B. (2004). Avanços na pesquisa de carotenóides em alimentos: contribuições de um laboratório brasileiro. Revista do Instituto Adolfo Lutz, 63, 129-138.

SAS Institute Inc. (2018). Statistical analysis system: release $9.4 m 6$. Cary, USA.

Schiedt, K., \& Liaaen-Jensen, S. (1995). Isolation and analysis. In G. Britton, H. Pfander \& S. Liaaen-Jensen (Eds.), Carotenoids (Vol. 1, Chap. 5, pp. 81-108). Switzerland: Birkhauser Verlag. 
Seabra, L. M. J., Damasceno, K. S. F. S. C., Silva, C. R., Gomes, C. C., \& Pedrosa, L. F. C. (2014). Carotenoides totais em resíduos de camarão Litopenaeus vannamei. Revista Ceres, 61(1), 130-133. http://dx.doi. org/10.1590/S0034-737X2014000100017.

Silva, F. O. 2010. Avaliação in vitro da atividade antioxidante dos carotenóides totais extraídos do músculo de camarões cultivados Litopenaeus vannamei (Dissertação de mestrado) Universidade Federal de Santa Catarina, Florianópolis. Retrieved from: https:// repositorio.ufsc.br/bitstream/handle/123456789/93996/280437. pdf? sequence $=1$ \&isAllowed $=y$

Silveira, N. F. A., Leitão, M. F. F., Baldini, V. L. S., \& Teixeira Filho, A. R. (2001). Bactérias produtoras de histamina e potencial para sua formação em peixes de origem fluvial ou lacustre. Brazilian Journal of Food Technology, 4, 19-25. Retrieved from: http://bjft.ital.sp.gov. br/arquivos/artigos/v04nu54a.pdf

Sowmya, R., \& Sachindra, N. M. (2012). Evaluation of antioxidant activity of carotenoid extract from shrimp processing byproducts by in vitro assays and in membrane model system. Food Chemistry, 134(1), 308-314. http://dx.doi.org/10.1016/j. foodchem.2012.02.147.

Stackebrandt, E., Reboli, A. C., \& Farrar, W. E. (2006). The genus Erysipelothrix. In M. Dworkin, M. Dworkin, S. Falkow, E. Rosenberg, K.-H. Schleifer \& E. Stackebrandt (Eds.), The Prokaryotes (pp. 492-510). New York: Springer. http://dx.doi. org/10.1007/0-387-30744-3_13.
Suseela, K. V., Criton, S., Patil, S., \& Gangadharan, G. (2015). A case of erysipeloid presenting as abscesses along the lymphatics. Journal of Academy of Clinical Microbiology, 17(1), 45-47. http://dx.doi. org/10.4103/0972-1282.158809.

Tapiero, H., Townsend, D. M., \& Tew, K. D. (2004). The role of carotenoids in the prevention of human pathologies. Biomedicine and Pharmacotherapy, 58(2), 100-110. http://dx.doi.org/10.1016/j. biopha.2003.12.006. PMid:14992791.

Wan Norhana, M. N., Poole, S. E., Deeth, H. C., \& Dykes, G. A. (2010). Prevalence, persistence and control of Salmonella and Listeria in shrimp and shrimp products: a review. Food Control, 21(4), 343-361. http://dx.doi.org/10.1016/j.foodcont.2009.06.020.

Wu, H., Niu, H., Shao, A., Wu, C., Dixon, B. J., Zhang, J., Yang, S., \& Wang, Y. (2015). Astaxanthin as a potential neuroprotective agent for neurological diseases. Marine Drugs, 13(9), 5750-5766. http:// dx.doi.org/10.3390/md13095750. PMid:26378548.

Yokoyama, V. A. (2007). Qualidade do camarão da espécie Xyphopenaeus kroyeri mediante a ação dos agentes antimelanóticos (Dissertação de mestrado). Escola Superior de Agricultura "Luiz de Queiroz", Universidade de São Paulo, Piracicaba. Retrieved from: https://teses.usp.br/teses/ disponiveis/11/11141/tde-28022008-154048/publico/vivianeyokohama.pdf

Yuan, J. P., Peng, J., Yin, K., \& Wang, J. H. (2011). Potential healthpromoting effects of astaxanthin: a high-value carotenoid mostly from microalgae. Molecular Nutrition \& Food Research, 55(1), 150165. http://dx.doi.org/10.1002/mnfr.201000414. PMid:21207519. 